\title{
HLA Class II Histocompatibility Antigen, DQ Alpha 1 Chain
}

National Cancer Institute

\section{Source}

National Cancer Institute. HLA Class II Histocompatibility Antigen, DQ Alpha 1 Chain. NCI

Thesaurus. Code C104987.

HLA class II histocompatibility antigen, DQ alpha 1 chain (254 aa, $28 \mathrm{kDa}$ ) is encoded by the human HLA-DQA1 gene. This protein is involved in modulation of peptide antigen binding and endocytosis. 